\title{
Identification of the $B, Q$, and native Brazilian biotypes of the Bemisia tabaci species complex using Scar markers
}

\author{
Paulo Roberto Queiroz ${ }^{(1)}$, Erica Soares Martins ${ }^{(1)}$, Nazaré Klautau(2), \\ Luzia Lima ${ }^{(3)}$, Lilian Praça ${ }^{(3)}$ and Rose Gomes Monnerat ${ }^{(3)}$
}

\begin{abstract}
(1)Instituto Mato-Grossense do Algodão, Rua Engenheiro Edgard Prado Arze, oㅡ 1.777, Edifício Cloves Vettorato, 2 Andar, Quadra 03, Setor A, Centro Político Administrativo, CEP 78049-015 Cuiabá, MT, Brazil. E-mail: pauloqueiroz@imamt.com.br, ericamartins@imamt.com.br (2)Universidade de Brasília, Instituto de Ciências Biológicas, Departamento de Genética e Morfologia, Campus Universitário Darcy Ribeiro, CEP 70910-900 Brasília, DF, Brazil. E-mail: nklautau@unb.br ${ }^{(3)}$ Embrapa Recursos Genéticos e Biotecnologia, Parque Estação Biológica, Avenida W5 Norte (Final), Caixa Postal 02373, CEP 70770-917 Brasília, DF, Brazil. E-mail: luzia.lima@embrapa.br, lilian.praca@embrapa.br, rose.monnerat@embrapa.br
\end{abstract}

Abstract - The objective of this work was to develop sequence-characterized amplified region (Scar) markers to identify the $\mathrm{B}, \mathrm{Q}$, and native Brazilian biotypes of the sweet potato whitefly [Bemisia tabaci (Hemiptera: Aleyrodidae)]. Random amplified polymorphic DNA (RAPD) amplification products, exclusive to the B and Brazilian biotypes, were selected after the analysis of 12,000 samples, in order to design a specific Scar primer set. The BT-B1 and BT-B3 Scar markers, used to detect the B biotype, produced PCR fragments of 850 and $582 \mathrm{bp}$, respectively. The BT-BR1 Scar marker, used to identify the Brazilian biotype, produced a PCR fragment of $700 \mathrm{bp}$. The Scar markers were tested against the Q biotype, and a flowchart was proposed to indicate the decision steps to use these primers, in order to correctly discriminate the biotypes. This procedure allowed to identify the biotypes that occur in field samples, such as the B biotype. The used set of primers allowed to discriminate the $\mathrm{B}, \mathrm{Q}$, and native Brazilian biotypes of $B$. tabaci. These primers can be successfully used to identify the $\mathrm{B}$ biotype of $B$. tabaci from field samples, showing only one specific biotype present in all cultures.

Index terms: Aleyrodidae, commodities, field samples, molecular marker, sweet potato whitefly.

\section{Identificação de biótipos $B, Q$ e nativo brasileiro do complexo da espécie Bemisia tabaci por meio de marcadores Scar}

\begin{abstract}
Resumo - O objetivo deste trabalho foi desenvolver marcadores "sequence-characterized amplified region" (Scar) para identificar os biótipos B, Q e nativo brasileiro da mosca-branca [Bemisia tabaci (Hemiptera: Aleyrodidae)]. Produtos de amplificação de DNA polimórfico amplificado ao acaso (RAPD), exclusivos aos biótipos B e nativo brasileiro, foram selecionados após análise de 12.000 amostras, para desenhar um conjunto de iniciadores específicos de Scar. Os marcadores Scar BT-B1 e BT-B3, usados para detectar o biótipo B, produziram fragmentos de PCR de 850 e 582 pb, respectivamente. O marcador Scar BT-BR1, utilizado para identificar o biótipo brasileiro, produziu um fragmento de PCR de $700 \mathrm{pb}$. Os marcadores Scar foram testados contra o biótipo Q, e um fluxograma foi proposto para indicar os passos para tomada de decisão sobre quando usar esses iniciadores, para discriminar corretamente os biótipos. Este procedimento permitiu identificar os biótipos que ocorrem em amostras de campo, como o biótipo B. O conjunto de iniciadores utilizados permitiu discriminar os biótipos $\mathrm{B}$, Q e nativo brasileiro de B. tabaci. Esses iniciadores podem ser utilizados com sucesso para identificar o biótipo B de B. tabaci em amostras de campo, e mostram apenas um biótipo específico presente em todas as culturas.
\end{abstract}

Termos para indexação: Aleyrodidae, commodities, amostras de campo, marcador molecular, mosca-branca.

\section{Introduction}

The sweet potato whitefly, Bemisia tabaci (Gennadius) (Hemiptera: Aleyrodidae), is a major pest of economically important crops worldwide (Xu et al., 2010). The pest status of B. tabaci insects is complicated by the recognition of 11 well-defined genetic groups and of at least 34 morphocryptic species, which are morphologically identical but distinguishable at the molecular level (De Barro et al., 2011).
In Brazil, the presence of two biotypes has been detected: one native (BR) and one introduced, known as biotype B (Rabello et al., 2008). The BR biotype is not very well studied (Alemandri et al., 2012), but the $\mathrm{B}$ biotype has been reported for its extensive list of host plants and high potential for virus transmission. A third biotype, known as the $\mathrm{Q}$ biotype, is considered to be highly resistant to insecticides, such as neonicotinoids and pyriproxyfen, and could result in greater damage 
than that caused by the B biotype (Crowder et al., 2007; McKenzie et al., 2012; Cuthbertson \& Vänninen, 2015). This biotype is on the A1 list of quarantine pests in Brazil and was recently detected in the country (Barbosa et al., 2015). The B and Q biotypes are very similar from a morphological and genetic viewpoint, which hinders their correct identification (Horowitz et al., 2005).

Sequence-characterized amplified region (Scar) molecular markers can be used for accurate identification of insects, including B. tabaci (Khasdan et al., 2005; Shankarappa et al., 2007). However, there are no Scar markers to identify the biotypes present in Brazil (BR and B) and the quarantined Q biotype. The establishment of a diagnostic process to identify these biotypes can be extremely beneficial for the identification and entry control of these biotypes in agricultural areas in Brazil, minimizing the damage these biotypes are likely to cause.

The objective of this work was to develop sequence-characterized amplified region (Scar) markers to identify the $\mathrm{B}, \mathrm{Q}$, and native Brazilian biotypes of the sweet potato whitefly (Bemisia tabaci).

\section{Materials and Methods}

For 5 years (between 2001 and 2006), 600 samples of approximately $20 \mathrm{~B}$. tabaci individuals were collected in different regions of Brazil, totaling 12,000 insects. These insects were previously identified as being of the B and BR biotypes, through morphological and molecular criteria (Martin et al., 2000; Lima et al., 2002), and were kept in the collection of whiteflies of Embrapa Recursos Genéticos e Biotecnologia in 70\% ethanol at $-20^{\circ} \mathrm{C}$.

The procedures of DNA extraction and random amplified polymorphic DNA (RAPD) amplification were carried out according to Lima et al. (2002). The RAPD primers used were: OPA-10: 5'GTG ATC GCA G3', OPA-13: 5'CAG CAC CCA C3', and OPA-15: 5'TTC CGA ACC C3'. The RAPD fragments specific to each B. tabaci biotype were separated in $1.5 \%$ agarose gel and were excised using a scalpel blade. The purification of the fragments was performed using the Concert Rapid Gel Extraction System (ThermoFisher Scientific, Inc., Waltham, MA, USA), and all molecular procedures were carried out as described by Sambrook \& Russell (2001). The RAPD fragments were cloned in the pGEM-T vector, according to the manufacturer's instructions (catalog item A1360, Promega, Madison,
WI, USA). Afterwards, the clones of the RAPD fragments were sequenced using the ABI Prism BigDye Terminator Cycle Sequencing Ready Reaction Kit, version 3.1, or the DYEnamic ET Terminator Matrix Standard, with the ABI-Prism 377 sequencer (Applied Biosystems, Waltham, MA, USA). The obtained sequences were analyzed using the BioEdit sequence alignment editor program (Hall, 1999), and new oligonucleotides were synthesized (Integrated DNA Technologies, Inc., Coralville, IA, USA) as Scar markers. The cloned sequences were deposited in the GenBank database under the accession numbers EF210443, EF210446, and EF210445.

Amplification reactions were performed in a $25-\mu \mathrm{L}$ reaction mixture containing $1 \mathrm{x}$ buffer $\left(10 \mathrm{mmol} \mathrm{L}^{-1}\right.$ Tris- $\mathrm{HCl} \mathrm{pH} 9.2,50 \mathrm{mmol} \mathrm{L}^{-1} \mathrm{KCl}$, and $0.1 \%$ Tween 20), $1.5 \mathrm{mmol} \mathrm{L}^{-1} \mathrm{MgCl}_{2}, 3.0 \mu \mathrm{mol} \mathrm{\textrm {L } ^ { - 1 }}$ of each Scar primer, $4.8 \%$ DMSO, $0.12 \mathrm{mmol} \mathrm{L}^{-1}$ dNTPs, $0.1 \mathrm{U} \mathrm{mL} \mathrm{m}^{-1} \mathrm{Taq}$ DNA polymerase (Amersham, Pharmacia Biotech, Inc., Piscataway, NJ, USA), and 100 ng DNA.

The primer sets designed after sequencing were: BT-B1-F (5'CGC AGA ATG TCT CAC TGC A3') and BT-B1-R (5'GCG GCA CCT TGT TGA CAG A3'), specific for the B biotype; BT-B3-F (5'GCA CCC ACG GAC ATT GAA AT3') and BT-B3-R (5'CCC ACT GTA TCC TTC GTC TCT3'), specific for the B and Q biotypes; and BT-BR1-R (5'CCG AAC CCT TTG GTG GAG GAT3') and BT-BR1 F (5'GGC GTG TTC CGC GAA TTC TGA3'), specific for the native Brazilian biotype. Amplifications were performed in a thermocycler PTC-100 (MJ Research, Inc., St. Bruno, Quebec, Canada) programmed for an initial step at $94^{\circ} \mathrm{C}$ for $3 \mathrm{~min}, 30$ cycles of denaturation at $94^{\circ} \mathrm{C}$ for $1 \mathrm{~min}$, annealing temperature $\left(63^{\circ} \mathrm{C}\right.$ for the BT-B1 and BT-B3 primers, and $63.5^{\circ} \mathrm{C}$ for the $\mathrm{BT}-\mathrm{BR} 1$ primer set) for $1 \mathrm{~min}$, and amplification at $72^{\circ} \mathrm{C}$ for $1 \mathrm{~min}$. A final extension step at $72^{\circ} \mathrm{C}$ for 5 min was performed.

The DNA fragments from Scar amplification were visualized in $1.5 \%$ agarose gel in TBE buffer (Tris-borate $90 \mathrm{mmol} \mathrm{L}^{-1}$ and EDTA $1.0 \mathrm{mmol} \mathrm{L}^{-1}$ ), and the images were analyzed using the Stratagene Eagle Eye Still Video System (Stratagene, Agilent Technologies, Santa Clara, CA, USA). Standard molecular-weight size markers 100-bp DNA ladder (Invitrogen, ThermoFisher Scientific, Inc., Waltham, MA, USA) were used in all agarose gels. 
Samples of B. tabaci stored in the collection of Embrapa, belonging to the B, Q, and BR biotypes, and samples from other species of whitefly and of other insect orders were used to validate the Scar markers (Table 1). To identify $B$. tabaci biotypes by Scar markers, samples from the following crops were collected: cauliflower (Brassica oleracea L. var. botrytis), cucumber (Cucumis sativus L.), tomato (Solanum lycopersicum L.), okra (Abelmoschus esculentus Moench), guava (Psidium guajava L.), and acai palm (Euterpe oleracea Mart.), in the municipality of São Luis, in the state of Maranhão, Brazil. A B biotype of $B$. tabaci was used as molecular control.

\section{Results and Discussion}

The Scar reactions of the B biotype of B. tabaci, developed from the OPA-10 and OPA-13 RAPD primers, produced specific fragments of 850 and 582 $\mathrm{bp}$, respectively. The BR biotype of B. tabaci produced a specific Scar fragment of $700 \mathrm{bp}$ when the OPA-15 RAPD primer was used. Therefore, the BT-B1 and BT-B3 Scar primer sets were initially developed to identify the B biotype of B. tabaci, and the BT-BR1 primer set was developed to distinguish the BR biotype (Figure 1).
The Scar primers were tested for their specificity. First, the three sets of primers were tested against several insect orders (Coleoptera, Diptera, Hemiptera, and Lepidoptera) (Table 1), and no amplicons were detected with any of the primers, confirming the specificity of the Scar markers to identify B. tabaci biotypes (Figures 1 and 2). Second, the three Scar sets of primers were tested to validate their ability to distinguish the biotypes of B. tabaci (Table 1), and the amplicons expected to be obtained for the B and BR biotypes were found. The BT-B1 Scar marker showed a specific fragment of 850 $\mathrm{bp}$, which was observed only in samples related to the B biotype of $B$. tabaci; the Q and BR biotypes in the PCR reactions using BT-B1 did not show this Scar marker. The BT-B3 primer pair was tested against B. tabaci and produced a 582-bp amplicon for the $\mathrm{B}$ and $\mathrm{Q}$ biotypes, indicating that the BT-B3 primer set was not efficient to immediately distinguish between the $\mathrm{B}$ and $\mathrm{Q}$ biotypes; however, this set of primers did not generate amplicons for the BR biotype. The use of the BT-BR1 primers in the PCR reaction produced the 700-bp Scar marker for the BR and Q biotypes, but the B biotype did not show this marker (Figure 2).

Based on these results, a flowchart was proposed to indicate the sequence of these primers in the PCR reactions, in order to use them to correctly identify the B, Q, and BR biotypes (Figure 3). The proposed

Table 1. Insect samples used to test the specificity of the sequence-characterized amplified region (Scar) markers to identify the whitefly Bemisia tabaci.

\begin{tabular}{|c|c|c|c|}
\hline Sample code & Country / Culture & Geographical position & Identification \\
\hline 7 & Morocco / Squash (Cucurbita moschata) & $33^{\circ} 56^{\prime} 6.81^{\prime \prime} \mathrm{N}, 6^{\circ} 51^{\prime} 28.19^{\prime \prime} \mathrm{W}$ & Bemisia tabaci Q biotype \\
\hline 14 & Spain / Tomato (Solanum lycopersicum) & $37^{\circ} 59^{\prime} 18.59^{\prime \prime} \mathrm{N}, 1^{\circ} 7^{\prime} 30.25^{\prime \prime} \mathrm{W}$ & Bemisia tabaci Q biotype \\
\hline 45 & Brazil / Cotton (Gossypium hirsutum) & $15^{\circ} 47^{\prime} 27.26^{\prime \prime} \mathrm{S}, 47^{\circ} 52^{\prime} 46.56^{\prime \prime W}$ & Bemisia tabaci BR biotype \\
\hline 75 & Brazil / Cucumber (Cucumis sativus) & $15^{\circ} 56^{\prime} 28.93^{\prime \prime S}, 50^{\circ} 8^{\prime} 6.93^{\prime \prime W}$ & Bemisia tabaci BR biotype \\
\hline 61 & United States / Tomato & $33^{\circ} 53^{\prime} 56.80^{\prime \prime} \mathrm{N}, 117^{\circ} 29^{\prime} 36.46^{\prime \prime} \mathrm{W}$ & Bemisia tabaci B biotype \\
\hline 110 & Brazil / Watermelon (Citrullus lanatus) & $12^{\circ} 31^{\prime} 40^{\prime \prime} \mathrm{S}, 40^{\circ} 18^{\prime} 25^{\prime \prime} \mathrm{W}$ & Bemisia tabaci B biotype \\
\hline 140 & Brazil / Soybean (Glycine max) & $23^{\circ} 11^{\prime} 31.44^{\prime \prime S}, 51^{\circ} 10^{\prime} 58.32^{\prime \prime W}$ & Bemisia tabaci $\mathrm{B}$ biotype \\
\hline 207 & Brazil / Cashew (Bertholletia excelsa) & $5^{\circ} 12^{\prime} 11.99^{\prime \prime S}, 37^{\circ} 19^{\prime} 30.58^{\prime \prime W}$ & Aleyrodicus cocois \\
\hline 226 & Brazil / Cotton & $15^{\circ} 43^{\prime} 52.36^{\prime \prime S}, 47^{\circ} 54^{\prime} 10.32^{\prime \prime W}$ & Bemisia tabaci BR biotype \\
\hline 228 & Brazil / Cassava (Manihot esculenta) & $12^{\circ} 23^{\prime} 35.97^{\prime \prime S}, 39^{\circ} 1^{\prime} 19.43^{\prime \prime W}$ & Aleurothrixus aepim \\
\hline 236 & Brazil/ Cassava & $22^{\circ} 16^{\prime} 25.19^{\prime \prime} \mathrm{S}, 54^{\circ} 11^{\prime} 1.08^{\prime \prime W}$ & Bemisia tuberculata \\
\hline 278 & United States / Citrus & $29^{\circ} 38^{\prime} 42.95^{\prime \prime N}, 82^{\circ} 20^{\prime} 47.02^{\prime \prime} \mathrm{W}$ & Aleurocanthus woglumi \\
\hline 281 & Brazil / Squash & $27^{\circ} 41^{\prime} 34.61^{\prime \prime S}, 48^{\circ} 49^{\prime} 16.28^{\prime \prime} \mathrm{W}$ & Trialeurodes vaporariorum \\
\hline 288 & Brazil / Tomato & $15^{\circ} 43^{\prime} 52.36^{\prime \prime S}, 47^{\circ} 54^{\prime} 10.32^{\prime \prime} \mathrm{W}$ & Bemisia tabaci B biotype \\
\hline ae & Brazil / Artificial diet & $15^{\circ} 43^{\prime} 52.36^{\prime \prime S}, 47^{\circ} 54^{\prime} 10.32^{\prime \prime} \mathrm{W}$ & Aedes aegypti \\
\hline ag & Brazil / Artificial diet & $15^{\circ} 43^{\prime} 52.36^{\prime \prime S}, 47^{\circ} 54^{\prime} 10.32^{\prime \prime} \mathrm{W}$ & Anticarsia gemmatalis \\
\hline ant & Brazil / Artificial diet & $15^{\circ} 43^{\prime} 52.36^{\prime \prime S}, 47^{\circ} 54^{\prime} 10.32^{\prime \prime W}$ & Anthonomous grandis \\
\hline sf & Brazil / Artificial diet & $15^{\circ} 43^{\prime} 52.36^{\prime \prime S}, 47^{\circ} 54^{\prime} 10.32^{\prime \prime W}$ & Spodoptera frugiperda \\
\hline $\mathrm{px}$ & Brazil / Artificial diet & $15^{\circ} 43^{\prime} 52.36^{\prime \prime S}, 47^{\circ} 54^{\prime} 10.32^{\prime \prime} \mathrm{W}$ & Plutella xylostela \\
\hline
\end{tabular}


flowchart starts using the BT-B3 primers in one PCR reaction. The initial decision step consists of the detection of the 850-bp DNA fragment. If the result is a positive amplification, a PCR reaction should be done using the BT-B1 pair of primers. If the result is negative, the next step is using the BT-BR1 primers to detect the BR biotype of $B$. tabaci. If the 700-bp DNA fragment is present, then the biotype detected is the BR biotype of $B$. tabaci. If no amplification is shown, the biotype is unknown. For the detection of the $\mathrm{B}$ biotype, if the BT-B3 set of primers shows the 582-bp fragment, the suspected biotype is probably the $\mathrm{B}$ biotype.
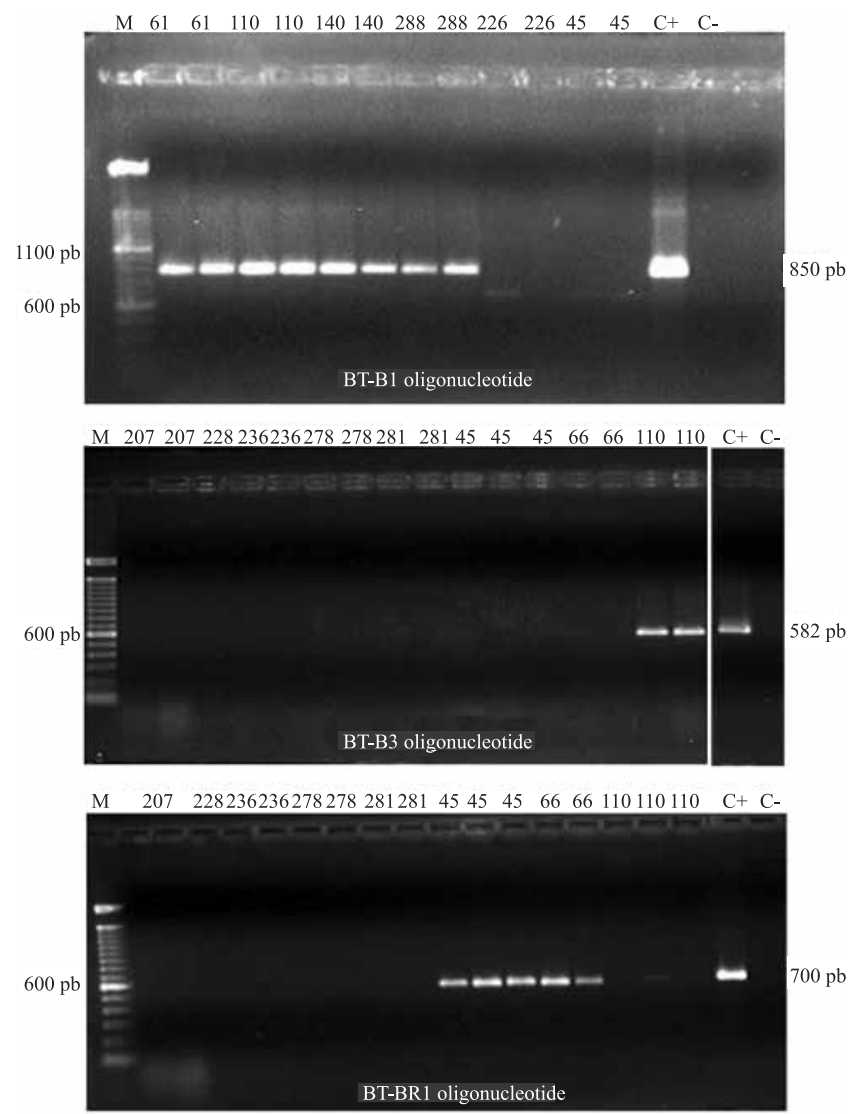

Figure 1. Sequence-characterized amplified region (Scar) analysis based on the BT-B1, BT-B3, and BT-BR1 primer sets. Codes are: 45, 66, and 226, Brazilian (BR) biotype of Bemisia tabaci; 61, 110, 140, and 288, B biotype of $B$. tabaci; 207, Aleyrodicus cocois; 228, Aleurothrixus aepim; 236, Bemisia tuberculata; 278, Aleurocanthus woglumi; and 281, Trialeurodes vaporariorum. C+, 850- and 582-bp RAPD fragment of the B biotype of B. tabaci, and 700-bp RAPD fragment of the BR biotype of $B$. tabaci cloned in the pGEM-T plasmid; and C-, negative control using Milli-Q water. M, 100-bp DNA ladder.

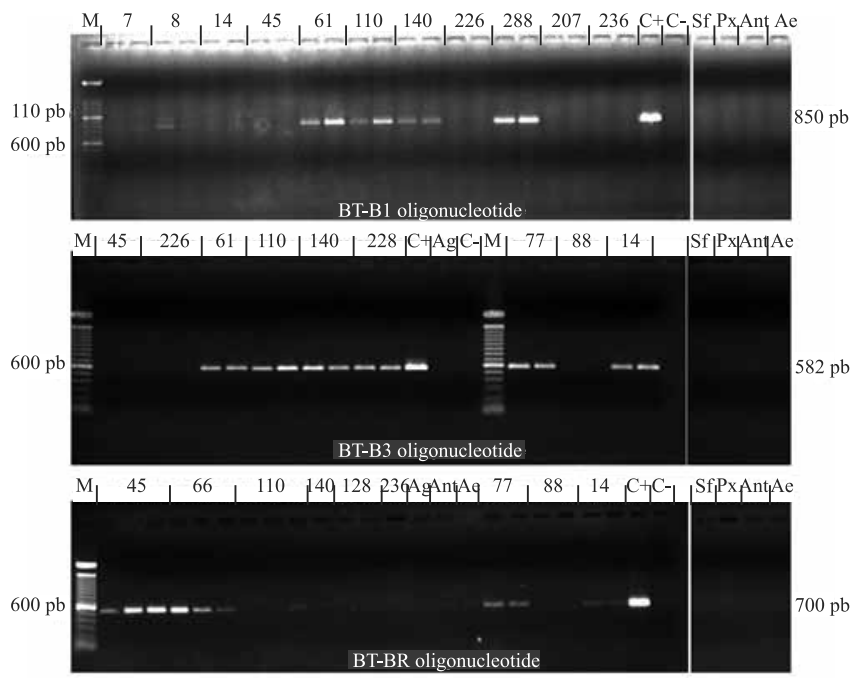

Figure 2. PCR reactions using the sequence-characterized amplified region (Scar) markers to distinguish the Brazilian (BR) and Q biotypes from the B biotype of the whitefly Bemisia tabaci. Numbers 7 and 14 indicate the Spanish and Moroccan Q biotype, respectively; 8, cassava (Manihot esculenta) biotype; 45, 66, and 226, BR biotype; and 61, 110, 140, 228, and 288, B biotype. The species used as a control were: 236 , Bemisia tuberculata; ae, Aedes aegypti; ag, Anticarsia gemmatalis; and ant, Anthonomous grandis. C+, RAPD fragment that originated the SCAR primers cloned in the pGEM-T plasmid; and C -, negative control using water. M, 100-bp DNA ladder.

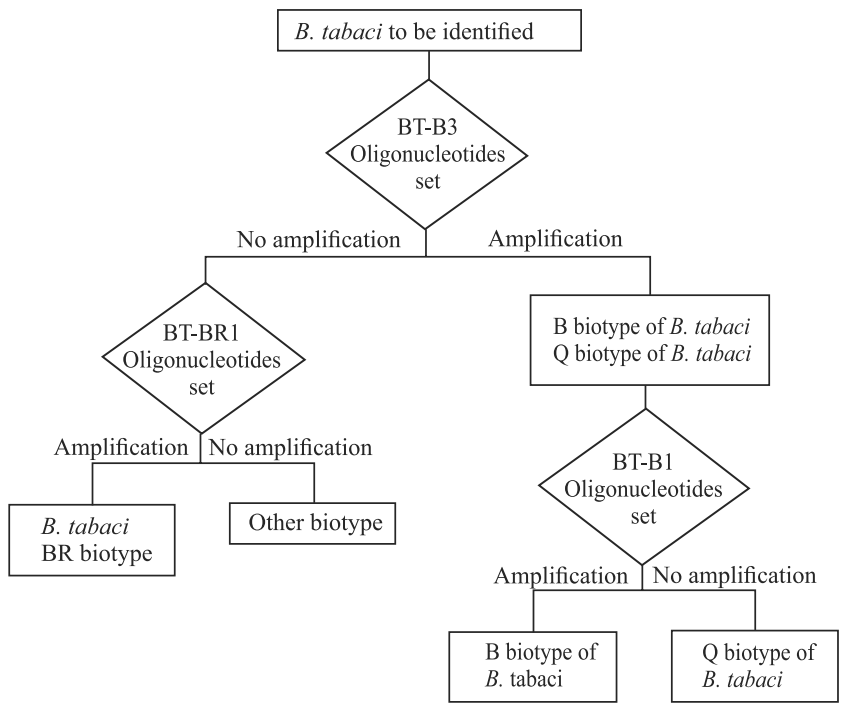

Figure 3. Flowchart showing the decision steps to use the sequence-characterized amplified region (Scar) markers in the routine identification of the $\mathrm{B}, \mathrm{Q}$, and Brazilian (BR) biotypes of the whitefly Bemisia tabaci. 
The flowchart strategy was tested to identify any biotype of $B$. tabaci collected directly from different crops located in the state of Maranhão, Brazil. Forty-six individuals of $B$. tabaci were analyzed, and presence of the B biotype was identified in the cultures of cauliflower, cucumber, okra, and tomato. However, in the cultures of guava and acai palm, all collected individuals did not produce the expected amplicon (Figure 4).

To confirm the Scar negative amplification with the samples of guava and acai palm, these samples were analyzed in the RAPD reaction using the OPA-13 primer to verify the integrity of the DNA. All negative

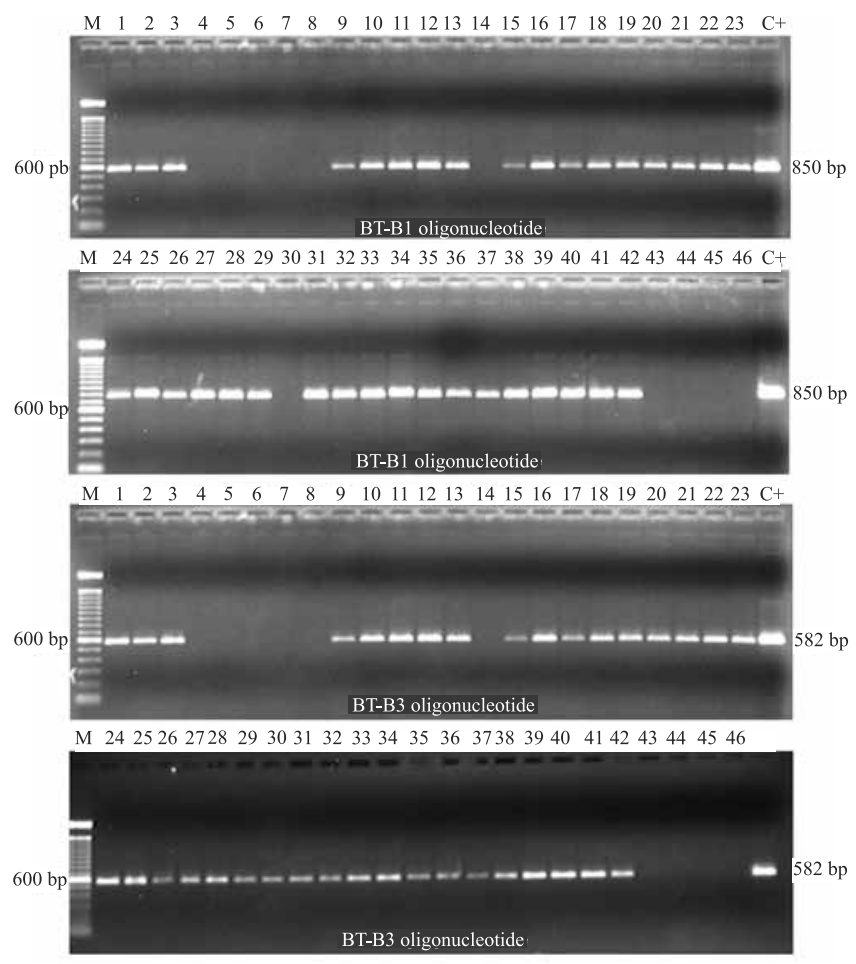

Figure 4. Identification of the $\mathrm{B}$ biotype of the whitefly Bemisia tabaci using the BT-B1 and BT-B3 primer sets in routine identification. The samples were collected in the following crops, in the state of Maranhão, Brazil: 1-3, cauliflower (Brassica oleracea var. botrytis); 4-8, guava (Psidium guajava); 9-13, cucumber (Cucumis sativus); 14-23, cauliflower; 24, B biotype collected in cauliflower from another area (Brasília) used as a control; 25-29, okra (Abelmoschus esculentus); 30-38, tomato (Solanum lycopersicum); 39-42, okra; and 43-46, acai palm (Euterpe oleracea). $\mathrm{C}+$, RAPD fragment that originated the SCAR markers cloned in the pGEM-T vector. M, 100-bp DNA ladder.
Scar samples produced a RAPD pattern that differed from that of the B biotype (Figure 5), suggesting the presence of one specific Aleyrodidae species different from the B. tabaci complex occurring in the Brazilian guava and acai palm crops.

The test of the BT-BR1 set of primers did not show any amplification signal related to the BR biotype in the analyzed samples. These results indicate the possibility of detecting the B biotype of B. tabaci directly from samples collected in the field. The advantage of the proposed Scar flowchart is the possibility of detecting the introgression of non-B biotypes, quickly dismissing other molecular and morphological techniques.

Interestingly, one individual from cucumber (sample 14) and one from tomato (sample 30) did not produce the desired amplicon with the BT-B1 primer set. These negative samples were tested against the BT-B3 primer sets, in which sample 14 did not produce the expected amplicon, but sample 30 did. To confirm the integrity of samples 14 and 30, a RAPD reaction was done using the OPA-13 primer, confirming the integrity of the DNA samples, because it was possible to identify a pattern of amplification in both of them. Sample 14 and 30 produced a RAPD pattern, but the one for sample 14 differed greatly from that for the other samples of B. tabaci collected in cucumber.
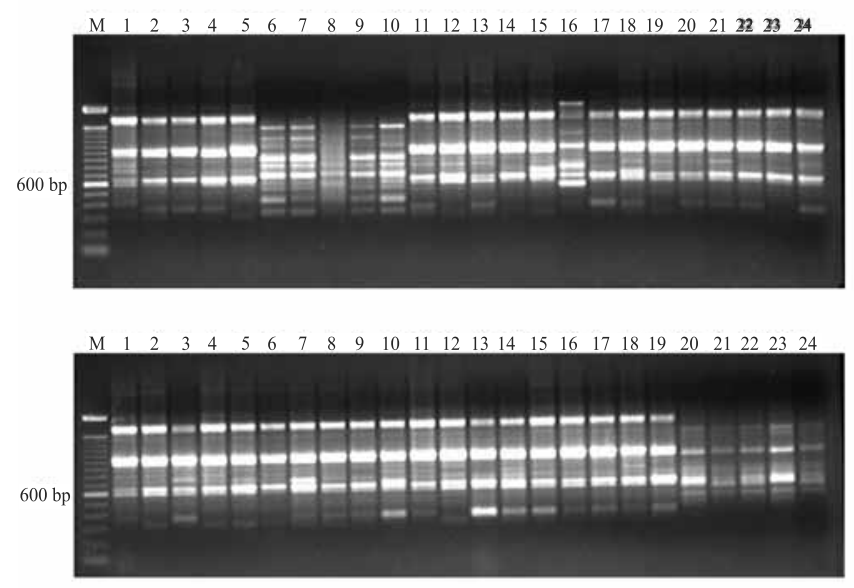

Figure 5. RAPD reaction using the OPA-13 primer of the samples used in the flowchart. 1-5, cauliflower (Brassica oleracea var. botrytis); 6-10, guava (Psidium guajava); 11-15, cucumber (Cucumis sativus); 16-20, cucumber; 21-24, cauliflower; 25-30, okra (Abelmoschus esculentus); 31-35, tomato (Solanum lycopersicum); 36-39, tomato; 40-43, okra; and 44-48, acai palm (Euterpe oleracea). M, 100-bp DNA ladder.

Pesq. agropec. bras., Brasília, v.51, n.5, p.555-562, maio 2016 DOI: $10.1590 / \mathrm{S} 0100-204 X 2016000500016$ 
Scar markers have the potential to identify biotypes of B. tabaci. This potential has been applied in insect molecular biology to discriminate the $\mathrm{B}$ and Q biotypes of $B$. tabaci occurring in eight areas in Israel (Khasdan et al., 2005), as well as to detect the B biotype of $B$. tabaci among biotypes indigenous to India (Shankarappa et al., 2007). In the present study, three sets of primers were developed, which were capable to distinguish Scar markers related to the B, Q, and BR biotypes of B. tabaci. Dong et al. (2007) and Qiu et al. (2009) failed to simultaneously compare the three major biotypes (B, Q, and $\mathrm{Cv}$ ) occurring in China, despite using RAPD and Scar markers for comparison, which are important to obtain the complete pattern of differences between these biotypes. These authors found differences between the $\mathrm{B}$ and $\mathrm{Cv}$ biotypes, but a high genetic similarity between the $\mathrm{B}$ and $\mathrm{Q}$ biotypes. These data confirm the difficulties found in the present study for the complete identification of biotypes through isolated Scar primer sets. For this reason, it was critical to develop a flowchart to efficiently identify the B, Q, and BR biotypes.

Information related to the BR biotypes was explored by Alemandri et al. (2012). These authors used a random amplified polymorphic DNA-polymerase chain reaction for diagnosis of all collected B. tabaci, which was also tested with previously published primers designed to work specifically with the BR biotype. These primers were either unable to distinguish between the two indigenous members of the complex in Argentina or indicated a difference when none was evident on the basis of mtCOI-sequence comparison. In the present work, a Scar set of primers was developed to identify this indigenous biotype of whitefly that probably occurs throughout America.

McKenzie et al. (2012) reported the great concern over the possibility of the development of a $\mathrm{B} / \mathrm{Q}$ hybrid. There are probably common annealing sites, present in the genomes of both biotypes, indicating the cross-amplification of the Scar marker developed to detect the B biotype of $B$. tabaci. Rabello et al. (2008) analyzed a 550-bp fragment related to the amplification of the ITS1 rDNA of the B and Q biotypes, which was digested by the AvaI, DdeI, and Sau3A restriction enzymes. These authors established a dendrogram, which showed $100 \%$ genetic similarity between both biotypes. Through this procedure, the authors did not identify any genetic difference between the B and Q biotypes.

Moya et al. (2001) showed that the crosses between the $\mathrm{B}$ and $\mathrm{Q}$ biotypes generated hybrids, such as $\mathrm{B} / \mathrm{Q}$, in the laboratory. These data could explain the cross-amplification observed for the Scar marker developed to detect the B biotype using the BT-B3 set of primers. This genetic effect could show why the 700-bp fragment was present only in sample 30, as revealed by the OPA-13 RAPD primer. Furthermore, the primers of the BT-B3 set could anneal in genomic sites that have common features in both biotypes, explaining the simultaneous amplification of the 582-bp Scar marker in both biotypes.

The test of these sets of primers to detect the Scar markers relative to the $\mathrm{B}$ and $\mathrm{BR}$ biotypes showed high efficiency in a routine procedure, because all samples produced the expected amplicons related to the biotypes (Figure 2). The presence of the B biotype of $B$. tabaci was confirmed in the cultures of cucumber, cauliflower, okra, and tomato. However, the BR biotype was not detected in any of the analyzed field samples, and B. tabaci collected in the cultures of guava and acai palm were also not related to the $\mathrm{B}$ biotype (Figure 4).

Shankarappa et al. (2007) developed a method to detect the B biotype using a system composed by silverleaf assay, esterases, and a RAPD or a Scar marker in combination or alone. However, other biotypes could not be identified. Some procedures, such as biochemical markers, are time consuming or present some limitations to their use on a large scale. Therefore, in the present study, the three sets of primers developed can be used to detect the B biotype quickly and showed potential to discriminate the $\mathrm{Q}$ biotype. It is important to highlight the amplification condition of the Scar sets of the BT-B1 and BT-B3 primers, since all primers can anneal at the same PCR temperature $\left(63^{\circ} \mathrm{C}\right)$. This fact could collaborate to increase the process of identification in which many samples could be identified by the flowchart with few steps of processing. It is worth noting that the adopted process of DNA extraction used one pipet tip and one plastic tube of $1.5 \mathrm{~mL}$ or less. Therefore, the process of identification of the biotypes of B. tabaci was optimized and was as quick as possible, contributing to solve important Brazilian quarantine tasks. Besides, because DNA sequencing is costly, the Scar method might be a more economical alternative than the mitochondrial analysis. 
The present study presents one molecular strategy to distinguish $B$. tabaci biotypes. Moreover, the procedure established was able to identify one native biotype occurring in Brazil (BR biotype). Once the electrophoresis profiles have been confirmed for the biotypes of $B$. tabaci, this information can be used for future work in the identification, monitoring, and dispersion of these biotypes of quarantine importance. In addition, much-needed further studies can be carried out to establish the relationships between the biology and the genetics of these insect populations, as those shown by the Q biotype, and to understand the real ecological situation of the BR biotype after the introduction of the $\mathrm{B}$ and $\mathrm{Q}$ biotypes of B. tabaci.

\section{Conclusions}

1. The BT-B1 and BT-BR1 sets of primers were able to identify the B and BR biotypes of the whitefly Bemisia tabaci through the 850 and 700 -bp amplicons, respectively.

2. The B and Q biotypes showed a similar 582-bp amplicon produced by the BT-B3 set of primers.

3. The use of the BT-B1, BT-BR1, and BT-B3 sets of primers in a flowchart can discriminate the $\mathrm{B}, \mathrm{BR}$, and Q biotypes of B. tabaci.

4. The flowchart established allows to identify the B biotype of $B$. tabaci in a set of samples collected directly from the field, and can be used to identify other Aleyrodidae present in the field samples.

\section{Acknowledgements}

To Desenvolvimento da Fruticultura Irrigada do Nordeste (Padfin) and to Conselho Nacional de Desenvolvimento Científico e Tecnológico (CNPq), for financial support.

\section{References}

ALEMANDRI, V.; DE BARRO, P.; BEJERMAN, N.; ARGÜELLO CARO, E.B.; DUMÓN, A.D.; MATTIO, M.F.; RODRIGUEZ, S.M.; TRUOL, G. Species within the Bemisia tabaci (Hemiptera: Aleyrodidae) complex in soybean and bean crops in Argentina. Journal of Economic Entomology, v.105, p.48-53, 2012. DOI: 10.1603/EC11161.

BARBOSA, L. da F.; YUKI, V.A.; MARUBAYASHI, J.M.; DE MARCHI, B.R.; PERINI, F.L.; PAVAN, M.A.; BARROS, D.R. de; GHANIM, M.; MORIONES, E.; NAVAS-CASTILLO, J.; KRAUSE-SAKATE, R. First report of Bemisia tabaci
Mediterranean (Q biotype) species in Brazil. Pest Management Science, v.71, p.501-504, 2015. DOI: 10.1002/ps.3909.

CROWDER, D.W.; DENNEHY, T.J.; ELLERS-KIRK, C.; YAFUSO, C.M.; ELLSWORTH, P.C.; TABASHNIK, B.E.; CARRIÉRE, Y. Field evaluation of resistance to pyriproxyfen in Bemisia tabaci (B biotype). Journal of Economic Entomology, v.100, p.1650-1656, 2007. DOI: 10.1603/0022-0493(2007)100[1650:FEORTP]2.0.CO;2.

CUTHBERTSON, A.G.S.; VÄNNINEN, I. The importance of maintaining Protected Zone status against Bemisia tabaci. Insects, v.6, p.432-441, 2015. DOI: 10.3390/insects6020432.

DE BARRO, P.J.; LIU, S.-S.; BOYKIN, L.M.; DINSDALE, A.B. Bemisia tabaci: a statement of species status. Annual Review of Entomology, v.56, p.1-19, 2011. DOI: 10.1146/ annurev-ento-112408-085504.

DONG, C.; GUO-FA, C.; BAO-YUN, X.; QING-JUN, W.; YOU-JUN, Z. RAPD analysis of population genetic structure of Bemisia tabaci biotype B and biotype Q. Acta Entomologica Sinica, v.50, p.264-270, 2007.

HALL, T.A. BioEdit: a user-friendly biological sequence alignment editor and analysis program for Windows 95/98/NT. Nucleic Acids Symposium Series, v.41, p.95-98, 1999.

HOROWITZ, A.R.; KONTSEDALOV, S.; KHASDAN, V.; ISHAAYA, I. Biotypes B and Q of Bemisia tabaci and their relevance to neonicotinoid and pyriproxyfen resistance. Archives of Insect Biochemistry and Physiology, v.58, p.216-225, 2005. DOI: $10.1002 / \operatorname{arch} .20044$.

KHASDAN, V.; LEVIN, I.; ROSNER, A.; MORIN, S.; KONTSEDALOV, S.; MASLENIN, L.; HOROWITZ, A.R. DNA markers for identifying biotypes B and Q of Bemisia tabaci (Hemiptera: Aleyrodidae) and studying population dynamics. Bulletin of Entomological Research, v.95, p.605-613, 2005. DOI: 10.1079/BER2005390.

LIMA, L.H.C.; CAMPOS, L.; MORETZSOHN, M.C.; NÁVIA, D.; OLIVEIRA, M.R.V. de. Genetic diversity of Bemisia tabaci (Genn.) populations in Brazil revealed by RAPD markers. Genetics and Molecular Biology, v.25, p.217-223, 2002. DOI: 10.1590/ S1415-47572002000200016.

MARTIN, J.H.; MIFSUD, D.; RAPISARDA, C. The whiteflies (Hemiptera: Aleyrodidae) of Europe and the Mediterranean Basin. Bulletin of Entomological Research, v.90, p.407-448, 2000. DOI: 10.1017/S0007485300000547.

MCKENZIE, C.L.; BETHKE, J.A.; BYRNE, F.J.; CHAMBERLIN, J.R.; DENNEHY, T.J.; DICKEY, A.M.; GILREIN, D.; HALL, P.M.; LUDWIG, S.; OETTING, R.D.; OSBORNE, L.S.; SCHMALE, L.; SHATTERS JR, R.G. Distribution of Bemisia tabaci (Hemiptera: Aleyrodidae) biotypes in North America after the Q invasion. Journal of Economic Entomology, v.105, p.753-766, 2012. DOI: 10.1603/EC11337ST1.

MOYA, A.; GUIRAO, P.; CIFUENTES, D.; BEITIAS, F.; CENI, J.L. Genetic diversity of Iberian populations of Bemisia tabaci (Hemiptera: Aleyrodidae) based on random amplified polymorphic DNA-polymerase chain reaction. Molecular Ecology, v.10, p.891-897, 2001. DOI: 10.1046/j.1365-294X.2001.01221.x. 
QIU, B.; CHEN, Y.; LIU, L.; PENG, W.; LI, X.; AHMED, M.Z.; MATHUR, V.; DU, Y.; REN, S. Identification of three major Bemisia tabaci biotypes in China based on morphological and DNA polymorphisms. Progress in Natural Science, v.19, p.713-718, 2009. DOI: $10.1016 /$ j.pnsc.2008.08.013.

RABELLO,A.R.; QUEIROZ,P.R.; SIMÕES, K.C.C.;HIRAGI, C.O.; LIMA, L.H.C.; OLIVEIRA, M.R.V.; EHTA, A. Diversity analysis of Bemisia tabaci biotypes: RAPD, PCR-RFLP and sequencing of the ITS1 rDNA region. Genetics and Molecular Biology, v.31, p.585-590, 2008. DOI: 10.1590/S1415-47572008000300029.

SAMBROOK, J.; RUSSELL, D.W. Molecular cloning: a laboratory manual. $3^{\text {rd }}$ ed. New York: Cold Spring Harbor Laboratory, 2001. 999p.
SHANKARAPPA, K.S.; RANGASWAMY, K.T.; NARAYANA, D.S.A.; REKHA, A.R.; RAGHAVENDRA, N.; REDDY, C.N.L.; CHANCELLOR, T.C.B.; MARUTHI, M.N. Development of silverleaf assay, protein and nucleic acid-based diagnostic techniques for the quick and reliable detection and monitoring of biotype B of the whitefly, Bemisia tabaci (Gennadius). Bulletin of Entomological Research, v.97, p.503-513, 2007. DOI: 10.1017/ S0007485307005251.

XU, J.; DE BARRO, P.J.; LIU, S.S. Reproductive incompatibility among genetic groups of Bemisia tabaci supports the proposition that the whitefly is a cryptic species complex. Bulletin of Entomological Research, v.100, p.359-366, 2010. DOI: 10.1017/ S0007485310000015.

Received on january 15, 2015 and accepted on december 10, 2015 